\title{
SISTEM KEKERABATAN MASYARAKAT KAMPUNG SAWAH DI KOTA BEKASI
}

\author{
Adon Nasrullah Jamaludin \\ UIN Sunan Gunung Djati Bandung \\ Email: adon.nasrullah@yahoo.co.id
}

\section{Abstract}

The phenomenon of population at Kampung Sawah Jatimurni District of Pondok Melati Bekasi shows that its people are not from ethnic Batak, but most of them are Sundanese and Betawinese. In the kinship structure of society of both ethnics, the term clan is unfamiliar. Rather it is known in the community of North Sumatra namely Batak. This paper focuses on describing how the people in Kampung Sawah uses the clan system and whether the surnames given in Kampung Sawah have similarities to those existing in Batak. Based on the data, the clan in Kampung Sawah is different from the one used in Batak, either in the marriage system, family system and socio-cultural system.

Fenomena masyarakat Kampung Sawah Kelurahan Jatimurni Kecamatan Pondok Melati Kota Bekasi, warganya bukan dari etnis Batak, tetapi kebanyakan dari etnis Sunda dan Betawi. Dalam struktur kekerabatan masyarakat etnis Sunda dan Betawi tidak dikenal istilah marga. Istilah marga lebih identik dan dikenal di masyarakat Sumatera Utara pada etnis Batak. Fokus tulisan ini adalah menjelaskan bagaimana masyarakat Kampung Sawah menggunakan sistem marga dan apakah nama marga yang dibangun oleh masyarakat Kampung Sawah Kota Bekasi memiliki kesamaan dengan marga yang ada pada etnis Batak. Berdasarkan data yang diperoleh bahwa marga yang ada di Kampung Sawah berbeda dengan marga yang ada di Batak, baik sisi sistem perkawinannya, sistem keluarga dan sistem sosial budayanya.

Keywords: marga, kekerabatan, etnis Sunda dan Betawi 


\section{Pendahuluan}

Sistem kekerabatan adalah hubungan kekeluargaan melalui perkawinan. Sebagaimana pendapat William A. Haviland (1985:73), bahwa keluarga adalah kelompok yang terdiri atas seorang ibu, anak-anak yang masih tergantung padanya, dan bapak yang diikat oleh perkawinan atau hubungan darah. Selain hubungan dalam satu keluarga, dikenal pula ada hubungan dengan keluarga-keluarga lain di luar dari keluarga mereka sendiri. Hubungan ini bisa dalam bentuk hubungan dengan para tetangganya, dan hubungan dengan para kerabat.

Istilah kerabat, dalam kamus antropologi didefinisikan sebagai orang sedaerah atau dekat sehingga disebut dengan kekerabatan (Suyono \& Siregar, 1985:196). Kerabat tersebut bisa dari pihak istri maupun kerabat dari pihak suami dan semua kerabat tersebut harus diperlakukan dengan baik. Kerabat merupakan pihak yang dekat kepada seseorang setelah keluarga sendiri, untuk itulah menjalin hubungan baik dengan kerabat menjadi sangat penting.

Secara garis besar, Indonesia mengenal tiga bentuk sistem kekerabatan, yaitu matrilineal, patrilineal, dan bilateral. Sistem kekerabatan matrilineal menarik garis keturunan dari pihak perempuan (ibu), misalnya suku Minangkabau. Sedangkan sistem kekerabatan patrilineal menarik garis keturunan dari pihak laki-laki (ayah), misalnya suku Batak. Sementara bilateral menarik garis keturunan dari kedua pihak, ayah dan ibu, misalnya suku Jawa.

Anggota kekerabatan terdiri atas ayah, ibu, anak, menantu, cucu, kakak, adik, paman, bibi, kakek, nenek dan seterusnya. Dalam kajian sosiologiantropologi, ada beberapa macam kelompok kekerabatan dari yang jumlahnya relatif kecil hingga besar. Tetapi yang perlu digaris bawahi adalah bahwa orang disebut berkerabat bukan hanya adanya ikatan perkawinan atau karena adanya hubungan keluarga, tetapi karena adanya hubungan darah (Koentjaraningrat, 1998:122). Anggota kelompok kekerabatan (keturunan) saling berkaitan karena mempunyai nenek moyang yang sama. Kelompok kekerabatan yang kecil disebut juga dengan keluarga batih. Sedangkan kelompok kekerabatan yang besar disebut dengan marga. Menurut Antonius (2006:80) marga merupakan suatu kesatuan kelompok yang mempunyai garis keturunan yang sama berdasarkan nenek moyang yang sama.

Di Indonesia daerah yang memiliki sistem kekerabatan dengan menggunakan nama marga yaitu daerah Sumatera Utara pada etnis Batak (Antonius, 2006:80). Batak adalah salah satu suku bangsa yang tidak hanya satu, tetapi terdiri dari beberapa sub suku. Suku bangsa yang dikategorikan 
sebagai Batak antara lain Batak Toba, Batak Karo, Batak Mandailing-Angkola, Batak Pakpak, dan Batak Simalungun (Kozok, 1999:12). Marga yang dipakainya merupakan identitas diri yang dibawa oleh setiap keturunan yang dilahirkan dalam perkawinan masyarakat adat Batak.

Suku Batak menerapkan garis keturunan patrilineal, yaitu garis keturunan berdasarkan garis ayah (bapak). Sehingga hanya anak laki-laki saja yang dapat membawa marga tersebut. Apabila perkawinan tersebut tidak menghasilkan keturunan laki-laki maka sama saja tidak menghasilkan keturunan sama sekali karena anak wanita tidak bisa meneruskan marga dan tidak dibenarkan mengangkat anak laki-laki orang lain. Begitu pula perkawinan yang dilakukan wanita Batak dengan pria bukan orang Batak berarti ia menghilangkan marga Bataknya karena suaminya tersebut tidak bisa menjadi penerus keturunan Batak.

Nama marga dalam suku Batak diambil dari nama Si Raja Batak. Si Raja Batak kemudian mempunyai keturunan dan nama-nama dari keturunannya inilah yang kelak berkembang menjadi marga-marga suku Batak. Turunan leluhur Si Raja Batak mendiami daerah "Sianjur Mula-Mula" (daerah Samosir). Kemudian sebagian besar dari mereka menyeberangi Danau Toba, lalu berpencar ke segala penjuru mendiami daerah-daerah yang ada di Sumatera Utara. Persebaran ini kemudian berkembang hingga keluar Sumatera Utara.

Di kalangan masyarakat Batak, sistem marga itu bertujuan untuk membina kekompakan dan solidaritas sesama anggota marga sebagai keturunan dari satu leluhur. Walaupun keturunan satu leluhur suatu saat nanti akan terbagi sebagai marga-marga cabang, namun sebagai keluarga besar marga-marga cabang tersebut akan selalu mengingat kesatuannya dalam marga pokoknya. Dengan adanya keutuhan marga, maka kehidupan sistem kekerabatan akan tetap lestari.

Hal yang unik dan menarik adalah masyarakat Kampung Sawah Kota Bekasi. Daerah ini berada di Provinsi Jawa Barat. Warganya bukan dari etnis Batak, tetapi kebanyakan dari etnis Betawi dan Sunda. Masyarakatnya memiliki sistem kekerabatan dengan menggunakan nama marga, sebagaimana halnya warga Batak. Etnis Sunda dan Betawi pada dasarnya tidak dikenal sistem kekerabatan dengan menggunakan nama marga.

Sistem kekerabatan orang Sunda bersifat bilateral artinya tidak menurut garis garis keturunan pihak ibu ataupun keturunan ayah (Koentjaraningrat, 1998:321). Dalam keluarga baik ibu atau ayah mempunyai kedudukan dan kewajiban yang sama terhadap anak-anak. Garis keturunan ibu atau ayah baik 
ke atas maupun ke bawah mempunyai derajat yang sama. Sehingga keluarga dalam Sunda merupakan tipe integrated family atau keluarga batih yang terdiri dari suami, istri dan anak-anak yang didapat dari perkawinan. Keluarga batih dalam masyarakat Sunda merupakan tempat yang paling aman bagi anggotanya ditengah-tengah hubungan kerabat yang lebih besar dan ditengah-tengah masyarakat (Koentjaraningrat, 1998:320). Bahkan dalam sistem kekerabatan orang Sunda tidak ada adat yang mewajibkan atau mengharuskan seorang anak menikah dengan anak keturunan tertentu, yang terpenting adalah asal tidak bertentangan dengan ketentuan agama. Begitupun pada masyarakat Betawi pada umumnya, tidak dikenal istilah marga.

Lain halnya pada masyarakat Betawi khususnya Kampung Sawah Kelurahan Jatimurni Kota Bekasi. Dalam struktur kekerabatan, masyarakatnya menggunakan sistem marga. Mereka mengklaim bahwa nama marga yang diambilnya, tidak diadopsi dari marga dalam batak. Marga yang dimaksud adalah salah satu bentuk pengikat keturunan mereka berdasarkan garis orang tua yang diberi sejak lahir, terutama garis bapak atau ayah. Kemudian memberi nama bapaknya diakhir dari nama depan seseorang itu, maka itulah dia marganya. Nama marga dalam masyarakat Kampung Sawah Kota Bekasi ini sudah ada dan terjaga sejak zaman kolonial Belanda. Jika dihitung-hitung sejak asal-usul nama marga ini ada, hingga sampai sekarang sudah memiliki sekitar 6-7 generasi (Praptanto, 2011:105).

Di antara nama-nama marga yang sering ditemui di Kampung Sawah adalah Napiun, Pepe, Kelip, Baiin, Kaiin, Kuding, Senen, Noron, Rikin, Kuding, Kaiin, Oyan, Biran, Seran, Rimin, Niman, Minan, Modo, Halim, Kadiman dan Nathanael (Praptanto, 2011:105). Sebagai contoh penulis ambil keluarga besar Bapak Napiun. Bapak Napiun (beragama Kristen) menikah dan memiliki anak, yaitu Sem, Tebeng, Yafet, Rapi, dan Kam. Kemudian anak Naipun yang bernama Kam (agama Kristen) menikah dengan seorang perempuan muslim bernama Dinah, dan mempunyai anak bernama Armon, Mari, Goyes, Dongkang, Tinah, dan Antonius Dempul. Untuk mengikat keluarga ini agar mudah dikenali, pihak keluarga menggunakan marga Napiun (sebagai kakeknya) di belakang nama anaknya, seperti Kam Naipun, Sem Naipun, Tebeng Naipun, Yapet Naipun dan seterusnya.

Ketika Kam Napiun memiliki istri kedua, dari pihak istri kedua, Kam Naipun memiliki memiliki tiga anak, yaitu Kaing, Jani, dan Jotang. Karena bermaksud untuk mengikat seluruh keturunan dari keluarga besar Napiun, maka anak Naipun yang memiliki anak dari istri keduapun sama diikat oleh 
marga, seperti Kaing Nipun, Jani Naipun, dan Jotang Naipun. Secara turuntemurun nama Napiun itu digunakan hingga ke anak, misalnya dari Jotang, lalu ke cucu-cucunya hingga ke cicit.

Berdasarkan uraian di atas, penulis tertarik untuk menulis kasus ini lebih jauh. Apakah nama marga yang dibangun oleh masyarakat Kampung Sawah Kota Bekasi memiliki kesamaan dengan marga yang ada dalam etnis Batak. Bahkan penggunaan nama marga dalam beberapa daerah seperti halnya Sumatera Utara (etnis Batak), sudah mulai pudar seiring perkembangan zaman. Tetapi pada masyarakat Kampung Sawah Kota Bekasi, justru penggunaan marga menjadi salah satu faktor integrasi atau menjadi kohesifitas sosial antar warga yang memiliki multi agama (Islam, Katolik dan Protestan).

\section{Metode Penelitian}

Penelitian ini dilakukan dengan mendasarkan pada filsafat fenomenologi yang mengutamakan penghayatan, terutama untuk menghayati apa yang ada dan yang tersembunyi di balik fenomena sosial. Metode deskriptif digunakan dalam penelitian ini mengingat kedalaman analisisnya yang lebih dimaksudkan untuk melukisjelaskan fakta-fakta di lapangan secara faktual, kemudian disajikan secara sistematis, sehingga lebih mudah dipahami dan disimpulkan.

Adapun teknik pengumpulan datanya melalui observasi langsung, wawancara mendalam, dan studi kepustakaan atau dokumentasi. Setelah data terkumpul, tahapan berikutnya adalah menganalisis data.

\section{Sejarah Marga pada Struktur Kekerabatan Masyarakat Kampung Sawah Bekasi}

Orang Kampung Sawah memiliki keunikan tersendiri yang sampai sekarang tetap terjaga yaitu nama marga. Tradisi Marga di daerah ini menjadi menarik, sebab hadir dalam kultur dan budaya orang Betawi. Padahal, budaya Betawi bukanlah kebudayaan daerah yang di dalamnya mengenal tradisi marga.

Tradisi marga yang berkembang di Kampung Sawah telah ada sejak zaman kolonial Belanda. Memang tidak tahu persis siapa orang yang pertama kali memproklamirkan nama marga di daerah tersebut. Pada saat ini, sudah ada sekitar 6-7 generasi sejak asal usul nama marga ini. Sumber lain (Praptanto, 2011:6), mengatakan bahwa tradisi marga di Kampung Sawah ada hubungannya sejarah kehadiran Kristen di Kampung sawah, sekitar tahun 1851 yaitu perkumpulan pengabaran Injil di Batavia (Belanda) Mr. Anthing dikenal sebagai pendiri gereja Kristen di kalangan penduduk pribumi, yang ditenggarai sejak ada zaman Belanda. 
Bahkan salah satu Gereja Kristen Pasundan (GKP), yang ada di Kampung Sawah menggunakan tradisi marga. Tradisi Marga adalah tradisi yang hadir dalam pola hubungan kekerabatan keluarga Jemaat GKP Kampung Sawah. Di Jemaat GKP Kampung Sawah, Tradisi Marga diberlakukan dengan cara membubuhkan nama leluhur laki-laki pada setiap nama belakang seseorang.

Begitupun dalam pandangan KH. Rahmadin Afif (Tokoh Masyarakat Kampung Sawah) bahwa dalam sejarahnya masuknya agama Kristen ke Kampung Sawah tidak terlepas dari kolonialisme Belanda (masa VOC). Saat itu menurutnya, Kampung Sawah telah menjadi daerah pembuangan, yaitu para buronan kriminal menyembunyikan diri.

Sejarah marga di Kampung Sawah berkaitan dengan masuknya Kristen karena penganut Kristen semakin banyak di Kampung Sawah, kemudian ada inisiasi dalam rangka mempererat jamaah diantara mereka, maka penganut Kristen membentuk nama marga, sebuah tradisi yang tidak ditemukan di Betawi lainnya. Nama marga adalah bentukan sistem hukum kolonial. Masa itu berlaku hukum Islam, adat, dan barat. Kolonial Belanda menerapkan sistem hukum yang berbeda pada masing-masing golongan masyarakat. Bagi warga Kristen bumi putera yang hendak menikah, berlaku peraturan khusus mirip hukum sipil Barat. Mereka harus menggunakan nama keluarga dari pihak ayah di belakangnya dan ditambah nama baptis.

Hingga saat ini antarwarga asli Kampung Sawah masih terikat hubungan kerabat, meski agama mereka berbeda-beda. Hubungan kerabat itu tak saja berupa hubungan darah, melainkan juga melalui jalur perkawinan beda agama. Ada yang kemudian melebur ke agama pasangannya. Ada juga yang bertahan pada agama masing-masing. Tetapi perkembangan selanjutnya, nama marga tidak lagi milik orang Kristen. Setelah terjadi perkawinan silang antara Islam dan Kristen yang terjadi di Kampung Sawah, maka nama marga semakin melebar. Yang perlu di garis bawahi adalah bahwa marga yang ada di Kampung Sawah berbeda dengan marga yang ada di Batak. Bahkan nama marga yang dimaksud bukan mengadopsi sistem marga pada warga Batak. Sebab di daerah ini sejak istilah marga berkembang tidak ada warga Bataknya. Tetapi marga yang dimaksud adalah salah satu bentuk pengikat keturunan mereka berdasarkan garis orang tua yang diberi sejak lahir, terutama garis bapak atau ayah.

Tradisi marga diberlakukan dengan cara membubuhkan nama leluhur laki-laki pada setiap nama belakang seseorang, yang adalah keturunan dari leluhur tersebut. Hal ini tidak jauh berbeda dengan pengertian marga secara 
umum, yaitu suatu kelompok kekerabatan yang berdasarkan atas keturunan melalui garis keturunan pihak laki-laki atau perempuan yang bersumber pada seorang leluhur (Widjaja, 1986:102).

Gejala ini disebut patrilineal, yaitu keturunan berdasarkan garis bapak. Model ini adalah garis keturunan unilineal, artinya seseorang tidak dapat memilih garis keturunannya, beda halnya dengan ambilineal adalah kebalikannya. Sehingga masing-masing keluarga dengan keturunannya memiliki marganya masing-masing. Ada beberapa nama marga yang sering dijumpai di Kampung Sawah. Mereka ini berarti orang pertama yang hidup dan tinggal di Kampung Sawah, kemudian berkembang hingga sekarang. Oleh karena itu, sangat mudah cara mengenali orang Kampung Sawah dengan melihat siapa nama terakhir dari nama seseorang itu, maka itulah dia marganya. Di antara nama marga yang ada di Kampung Sawah hampir dua puluh lebih diantaranya: Napiun, Pepe, Kelip, Baiin, Saiman, Dani, Sabajan, Jilin, Empit, Peking, Emeng, Centeng, Cimi, Kuding, Senen, Noron, Rikin, Kuding, Kari'in, Oyan, Baidan, Seran, Rimin, Niman, Minan, Modo, Halim, Kadiman, dan Nathanael.

Hasil wawancara penulis dengan sejumlah tokoh masyarakat dan agama yang ada bahwa masyarakat Kampung Sawah antara keluarga yang satu dengan yang lain masih terikat hubungan persaudaraan. Jika diruntut satu dengan yang lainnya, mereka berasal dari keturunan yang sama baik dari pihak kakek maupun nenek. Istilah mereka "berasal dari satu pu'un". Agar keturunan ini tidak bercerai berai, mereka mengikatnya dengan sistem kekerabatan yang hingga saat ini masih tetap terjaga, yaitu diberinya nama marga.

Sebagai contoh penulis mengambil marga Napiun. Keluarga ini masih ada keturunannya di Kampung Sawah. Napiun adalah termasuk generasi pertama yang tinggal di Kampung Sawah. Bapak Napiun (beragama Kristen) menikah dan memiliki anak, yaitu Sem, Kam (Ta'im), Tebeng, Yafet, Rapi, dan Jabun. Ini adalah generasi kedua. Anak Naipun yang bernama Kam (agama Kristen) menikah dengan seorang perempuan muslim bernama Dinah, dan mempunyai anak bernama Armon, Mari, Goyes, Dongkang, Tinah, dan Antonius Dempul. Sedangkan anak Napiun yang bernama Yapet (agama Kristen) menikah dengan seorang perempuan dari marga Modo, mempunyai anak yaitu Neri, Mentinah, Semon, Welmin, Kocam, Lukas, Benyil, Katin, dan Omi. Ini adalah contoh generasi ketiga.

Anak Yapet yang bernama Semon menikah dengan seorang perempuan dari marga Dani mempunyai anak yaitu Boeng. Boengpun kemudian kawin mempunyai anak yang bernama Manuel. Bapak Manuel inilah hingga saat ini 
masih hidup dan merupakan generasi ke-5 dari keluarga besar Napiun. Untuk mengikat keluarga ini agar mudah dikenali, pihak keluarga menggunakan marga Napiun di belakang nama anaknya, seperti Kam Naipun, Sem Naipun, Tebeng Naipun, Yapet Naipun dan seterusnya.

Sebagai contoh, keluarga besar Marga Dani. Keluarga ini masih ada keturunannya di Kampung Sawah. Dani adalah termasuk orang generasi pertama yang tinggal di Kampung Sawah. Bapak Dani menikah dan mempunyai anak bernama Atin, Suradi, Kleopas dan Marya. Anak Dani yang bernama Kleopas kawin dan mempunyai anak bernama Musa dan Klarina. Bapak Musa yang berumur 87 Tahun, hingga saat ini masih hidup dan merupakan generasi ke-3 dari keluarga besar marga Dani. Merekapun sama, untuk mengikat keluarga ini agar mudah dikenali, pihak keluarga menggunakan marga Dani di belakang nama anaknya, seperti Musa Dani, Atin Dani dan lainnya. Begitupun dengan cucu dan cicitnya. Musa Dani kawin dengan marga Napiun mempunyai anak bernama Anugrah. Maka Anugerah sebagai cicit, menambah namanya dengan nama marga menjadi Anugerah Dani dari keturunan Musa.

\section{Sistem Perkawinan, Sistem Keluarga, dan Sistem Sosial-Budaya Masyarakat Marga Kampung Sawah Bekasi}

\section{Sistem Perkawinan}

Hal yang manarik dari sistem marga di Kampung sawah yaitu perkawinan. Marga di Kampung Sawah tidak memperbolehkan kawin dalam satu marga (misalnya marga Napiun dengan marga Napiun sendiri). Mereka memperbolehkan kawin antar marga (misalnya marga Napiun dengan marga Dani) walaupun berlainan agama. Justru dengan adat seperti itu sistem kekerabatan masyarakat Kampung Sawah menjadi luas dan kuat, meski agama mereka berbeda-beda. Hingga saat ini keragaman pemeluk agama di Kampung sawah tidak pernah menjadi konflik, sebab diikat oleh antar marga mereka sendiri, melalui jalur perkawinan.

Penulis mengambil sampel keluarga Bapak Yohanes Dani (warga masyarakat Kampung Sawah). Dia memiliki istri (orang Kristen) bernama Elizabet, mempunyai lima anak yaitu Veronika, Ruginah, Agustinus, Marcelio, dan Alexander. Seluruhnya beragama Kristen Katolik. Belakangan sekitar tahun 2010, anak beliau Veronika kawin dengan lelaki muslim bernama Husaini. Akhirnya Veronika pindah menjadi muslim ikut suami dan tinggal di Kampung Sawah. Penulis sempat mewawancarai kepindahan agama 
mereka. Veronika sempat menjawab bahwa kepindahan agama mereka lebih disebabkan ikut suami. Mereka tidak menyesali, sebab di Kampung Sawah menurutnya perpindahan agama menjadi sesuatu yang biasa. Hal ini berdasarkan atas kesadarannya sendiri.

Itupun diakui oleh ayahnya Veronika, Bapak Yohanes, bahwa tradisi di Kampung Sawah urusan agama diserahkan masing-masing anak. Sebab hal ini akan menjadi pilihan dalam hidupnya, asalkan dengan kesungguhan dan kesadaran dari dirinya. Begitu juga dialami oleh keluarga Bapak Edi, kemudian Bapak Joni. Beliau juga mengalami hal yang sama, tetapi hal itu dianggap sesuatu yang lumrah dan biasa pada tradisi beragama Kampung sawah.

Begitupun dengan keluarga Bapak Manuel Boeng Napiun. Kakek dan neneknya beragama Kristen Katolik. Anak-anak dan cucunya ada yang beragama Islam, Kristen juga Hindu. Bahkan keluarga Bapak Manuel Boeng Napiun sendiri, memiliki ragam agama. Anaknya ada yang Kristen Protestan dan ada yang Islam bahkan sudah naik haji. Begitupun dengan keluarga Pengasuh Pondok Pesantren Fisabilillah (Yasfi) KH. Rahmadin Afif. Beliau tokoh masyarakat Islam di Kampung Sawah, beliau mengatakan bahwa kakeknya masih ada hubungan keluarga dengan kakek Musa Dani (87 Tahun), sesepuh Protestan di Kampung Sawah.

Oleh karena itu, tidaklah aneh di Kampung Sawah akan dijumpai dalam satu keluarga atau satu keturunan memiliki ragam pemeluk agama baik Islam maupun Kristen. Mereka bersaudara walaupun berbeda agama. Tetapi yang menarik adalah pada saat perkawinan yang seagama (Kristen dengan Kristen), nama marganya tetap ada dan dipakai di belakang namanya. Lain halnya, jika pindah ke Islam terkadang nama marganya menjadi hilang dan tidak dipakai, atau kadang dipakai tetapi dengan disingkat saja, kemungkinan berubah menjadi bin bukan marga.

Kemudian berkaitan dengan adat dan sistem perkawinannya, dari mulai perkenalan hingga proses perkawinannya mengikuti adat Betawi, bukan Batak. Biasanya dalam perkawinan adat Betawi dimulai perjumpaan dan pendekatan, lamaran sampai dengan akad nikah yang merupakan peresmian seorang pemuda dan seorang gadis menjadi suami istri serta pesta yang melengkapinya. Prosesnya dimulai dari hal-hal ngelancong, ngelamar, seserahan, dan hajatan atau keriaan (pesta perkawinan). Beberapa budaya setempat yang seringkali dipakai dalam acara perkawinan adalah tanjidor, gambang kromong, topeng betawi, wayang kulit betawi, dan lainnya. 


\section{Sistem Keluarga}

Keluarga dalam pandangan masyarakat marga Kampung Sawah, adalah sepasang suami isteri, yang lambat laun terus berkembang menjadi beberapa keluarga dari keturunannya hingga merupakan sebuah kumpulan rumah tangga, sekampung, sedesa dan seterusnya hingga menjadi keluarga luas karena anak beranak mungkin sampai tujuh turunan (anak-incu-buyut-bao-jangga warengudeg-udeg-gantungsiwur) yang bisa terpencar jauh rumah tangganya. Untuk mengikat keluarga yang besar tersebut dan terpencar ke berbagai daerah, maka diikat dengan nama marga. Hal ini dilakukan untuk tetap terjalin dan terikat antar keluarga yang berserakan tersebut.

Tetapi pada dasarnya keluarga mereka juga adalah keluarga batih (keluarga inti) terdiri dari suami-istri atau ayah, ibu dan anak-anak yang belum kawin. Suami berperan sebagai kepala rumah tangga dan bertanggung jawab atas keselamatan dan kelangsungan hidup anggota keluarga serta sebagai pencari nafkah. Ibu bertugas sebagai pengurus rumah tangga dan pengasuh anakanak. Ada kalanya anggota keluarga lain di luar keluarga batih ikut bersama tingggal baik dari pihak ibu atau ayah.

Melihat sistem keluarga yang ikat oleh marga di Kampung Sawah, bahwa sistem kekerabatan model Kampung Sawah memperkuat teori tentang kelompok keturunan. Bahwa fungsi utama dari pengetahuan atas kelompok keturunan adalah dalam rangka pembentukan kelompok-kelompok sosial terutama pada masyarakat unilineal tradisional (Meinarno, 2011:155). Berdasarkan teori tersebut sistem kekerabatan model marga yang ada di Kampung Sawah secara tidak langsung menguatkan fungsi keluarga secara umum yaitu memberi perlindungan, afeksi, pengasuhan dan pendidikan kepada anggota keluarganya (Meinarno, 2011:151). Oleh karena itu, sistem kekerabatan yang dibangun oleh masyarakat Kampung Sawah secara tidak langsung menguatkan integratif masyarakat atau kohesifitas sosial. Sistem kekerabatan yang dibangun secara tidak langsung mampu menguatkan fungsi kelurga, di antaranya mempertahankan nilai, menegakan norma, dan itu menjadi bagian dari proses enkulturasi yaitu proses kemasyarakatan yang bersifat lintas generasi dan memungkinkan manusia untuk menyampaikan dan belajar tentang kebudayaannya.

Proses ini yang dibangun di keluarga-keluarga yang termarga di Kampung Sawah. Proses enkulturasi sangat tampak seperti mereka mengajarkan kepada keturunannya (anak keturunannya) bahwa di Kampung Sawah selain agama Islam juga ada agama Kristen sehingga diajarkan tentang hidup saling 
menghargai, menghormati walaupun berbeda agama dan pendapat. Ini adalah proses pembelajaran nilai dan norma hidup dalam pluralitas (kemajemukan agama), sehingga akan membentuk sikap saling menghormati serta menyayangi diantara mereka.

3. Sistem Sosial Budaya

Pendekatan sistem sosial-budaya pada masyarakat marga di Kampung Sawah, yang dimaksud disini adalah penulis melihat melalui kegiatan-kegiatan sosial kemasyarakatan warga marga Kampung Sawah dengan melibatkan seluruh masyarakat marga baik agama maupun suku tanpa adanya diskriminasi. Sedangkan pendekatan sistem budaya, penulis melihat bahwa masyarakat memiliki nilai umum dan bersama dalam marga mereka. Nilai umum yang dimaksud adalah semua masyarakat mengakui dan menerima dan berlaku bagi masyarakat marga setempat. Melalui penganutan nilai umum ini, diharapkan menjadi perekat bagi semua anggota masyarakat khususnya marga yang ada di Kampung Sawah. Nilai-nilai umum itu bersumber pada budaya yang ada pada masyarakat yang menjadi acuan perilaku yang terpola.

4. Pendekatan Sistem Sosial

Pada pendekatan sistem sosial, masyarakat marga Kampung Sawah telah melakukan sejumlah kegiatan-kegiatan yang berifat kemasyarakatan. Kegiatan ini, telah menjadikan masyarakat marga saling berhubungan, berinteraksi serta berkomunikasi antara satu dengan yang lainnya tanpa membedakan kepentingan dan golongan diantara mereka. Beberapa kegiatan tersebut, diantaranya gotong royong dan sistem keamanan lingkungan.

5. Pendekatan Sistem Budaya

Sedangkan melalui pendekatan sistem budaya, marga yang ada di Kampung Sawah memiliki beberapa tradisi yang berkaitan dengan nilai, norma dan budaya. Ketiga sistem budaya mengikat warga untuk saling bersatu, bersama dan menjaga. Marga yang ada di Kampung Sawah identik dengan orang Betawi, yaiitu kategori Betawi pinggiran atau Betawi Ora. Biasanya Betawi ini berada di pinggiran atau diluar Kota Jakarta, salah satunya adalah Kampung Sawah. Orang Betawi marga Kampung Sawah memiliki sejumlah nilai, norma dan budayanya, yang tercermin dalam bahasanya (dialek), kesenian, pakaian, makanan, dan sistem keyakinan dalam agama dan lainnya. Diantaranya: (1) Bahasa, sifat campur-aduk dalam dialek bahasa orang Marga Kampung Sawah adalah cerminan dari kebudayaan Betawi secara umum, yang merupakan hasil perkawinan berbagai macam kebudayaan, baik yang berasal dari daerah-daerah lain di Nusantara maupun kebudayaan asing; (2) kesenian dan kebudayaan, marga 
Kampung Sawah masih memiliki seni Gambang Kromong yang berasal dari seni musik Tionghoa, tetapi juga ada Rebana yang berakar pada tradisi musik Arab, Keroncong Tugu dengan latar belakang Portugis-Arab dan Tanjidor yang berlatar belakang ke-Belanda-an. Saat ini Suku Betawi terkenal dengan seni Lenong, Gambang Kromong, Rebana Tanjidor dan Keroncong. Sifat campur-aduk dalam dialek Betawi adalah cerminan dari kebudayaan Betawi secara umum, yang merupakan hasil perkawinan berbagai macam kebudayaan, baik yang berasal dari daerah-daerah lain di Nusantara maupun kebudayaan asing; (3) pakaian dan makanan, Marga Kampung Sawah memiliki kerajinan batik sebagai salah satu dari seni tekstil Betawi. Tekstil Betawi terkenal akan nuansa warna dan ragam, dengan ciri khas nuansa kesenian Betawi yang dipengaruhi oleh budaya Cina, Timur Tengah, dan Eropa. Hal ini terjadi karena begitu banyak akulturasi dari berbagai kebudayaan asing dan lokal yang terjadi di Betawi. Motif Buketan, Liong, dan Lokcan atau Burung Hong terdapat pada batik Betawi pengaruh Cina. Sementara itu dari sisi makanan, masyarakat Betawi juga memiliki wisata kuliner yang lezat, baik makanan pembuka, utama, maupun jajanan pasar. Gaya kuliner Betawi sangat beragam, berbeda lokasi sudah ada sentuhan rasa yang berbeda, misalnya Laksa dan Soto Betawi. Umumnya Laksa Betawi berkuah kuning, sedangkan kuah Soto Betawi beragam, ada yang berkuah santan putih kekuningan tanpa potongan tomat dan kentang goreng; berkuah kemerahan dengan isi komplot, ada emping, tomat, dan kentang goring; (4) sistem keyakinan, unsur yang memperkuat pada budaya orang Betawi khususnya marga Kampung Sawah adalah agama itu sendiri, dengan segala sistem keyakinan, nilai-nilai serta kaidah-kaidahnya. Mohamad Sobary, pernah menyebut tentang ini, bahwa Betawi baru bisa dipahami dan dimengerti secara utuh bila kita memahami juga Islamnya (Effendi, 1996:595). Semua orang Betawi penganut Islam yang taat. Bahkan agama menjadi salah satu unsur penting yang mengikat mereka dan member cirri sebagai satu kelompok etnik. Sebagaimana halnya Mohamad Sobari diatas, hal senada H. Mahbub Junaidi dalam M. Junus Melalatoa (1997:165), mengatakan bahwa kebudayaan Betawi sebagai satu subkultur hampir tidak bisa dipisahkan dengan Islam. Mustahil bagi orang Betawi hidup tanpa bersentuhan dengan langgar dan masjid, jika tidak taat beragama dia akan terkucil dalam arti yang sebenar-benarnya.

Begitupun masyarakat Betawi Kampung Sawah, pada dasarnya dan dari awalnya mereka memiliki sejumlah sistem budaya dengan nilai-nilai, norma dan budaya yang menjadi acuan dalam berbagai tindakannya. Hal itu 
diwujudkan dalam sikap, perilaku, dan tingkah laku sehari-harinya. Misalnya arus urbanisasi yang masuk ke Kota Bekasi, dan kebetulan ke Kampung Sawah tidak sebanyak wilayah lainnya di Kota Bekasi, telah menimbulkan kultur yang sangat majemuk. Tetapi diantara kehidupan itu, orang Betawi menanggapinya dengan sikap toleransi yang tinggi. Mereka sangat lentur dalam menanggapi berbagai pengaruh dari luar dan dari dalam. Toleransi itu ditunjukkan dengan sikap yang lebih kongkrit berupa keramah-tamahan. Nilai ini sudah terbentuk dalam pribadi-pribadi orang Betawi. Keramah- tamahan terarah kepada siapa saja termasuk kepada orang lain yang belum dikenalnya.

Kemudian mereka juga mewujudkan nilai hidup rukun di keluarga dan antar warga, lebih-lebih antar marga mereka. Kerukunannya didasarkan kepada nilai saling menghormati, yang muda menghormati yang tua, istri menghormati suami, yang tua menyayangi, mengasihi yang lebih muda serta membimbingnya. Hidup rukun pula harus mewarnai kehidupan masa-masa susah bukan saat kaya saja. Misalnya tidak makan pada waktu yang seharusnya makan (mindo), menjual hanya seekor ayam ke pasar untuk menghadapi lebaran, malam gelap tanpa pelita (lampu tempel), minjam uang kepada tetangga tidak punya uang. Ini semua tidak menggoyahkan suasana rukun dalam rumah tangga. Demikian kira-kira gambaran gaya hidup dan nilai yang dibangun oleh orang Betawi Kampung sawah.

Bahkan wujud lainnya adalah gaya hidup sederhana, tidak berlebihan, dan dengan sabar menerima keadaan serta kemudahan yang diberikan oleh lingkungan sekitarnya. Solidaritas terhadap lingkungannya cukup tinggi, baik dalam suka maupun duka. Mereka juga mengamalkan azaz mufakat dalam mengambil keputusan dalam lingkungan kehidupan kerabat dan lingkungan sosial yang lebih luas. Semua itu langsung atau tidak langsung terkait dengan norma dan nilai ketaqwaan kepada Allah Swt berdasarkan ajaran agama Islam.

Di samping nilai dan norma yang berumber dari ajaran Islam, kemudian dipraktekan dalam kehidupannya sehari-hari, masyarakat marga Kampung Sawah juga memiliki budaya yang masih dipegang dan menjadi tradisi dalam kehidupannya. Justru tradisi yang dipegang dari budaya-budaya yang ada, mampu menyatukan sikap pandang warga Betawi Kampung Sawah. Mereka tidak tersekat dalam kotak-kotak layaknya organisasi dan golongan. Tetapi tradisi yang dipegang mampu mengikat mereka dari sekat-sekat yang ada, baik sekat etnis, agama atau kepentingan lainnya. Bisa dibuktikan dalam pembahasan sebelumnya, bahwa tradisi seperti sedekah bumi, membuat dodol Betawi, atau 
tradisi saat panen tiba telah menjadi acara rutinan dan menjadi tardisi turun temurun, untuk secara bersama-sama berkumpul dari berbagai golongan. Kegiatan ini tidak dimiliki oleh wilayah lain yang ada di Kota Bekasi.

Arus perubahan zaman yang lebih cepat di wilayah lain, telah menyeret sekaligus mengikis kearifan lokal setempat. Kampung Sawah yang masih perkampungan, ternyata masih mampu mempertahankan tradisi tersebut sebagai wahana penyatu paduan masyarakat yang ada. Dengan cara seperti ini pula, disamping apresiasi terhadap nenek moyangnya yang telah mengukir terciptanya budaya, juga menjadi alat pemersatu masyarakat Kampung Sawah.

\section{Sistem Perekonomian}

Sistem perekonomian yang berkembang, juga menjadi salah satu ciri dari kehidupan sosial marga di Kampung sawah. Komunikasi bermasyarakat dapat terlihat dalam aneka kegiatan perekonomian yang tidak dibatasi oleh perbedaan suku, agama dan budaya. Ini terlihat dari interaksi masyarakat ketika berada dipusat-pusat kegiatan perekonomian warga Kampung Sawah, seperti pasar, koperasi, warung-warung makan, pangkalan ojeg, becak, delman dan lainnya.

Pada masa lalu masyarakat Kampung Sawah hidup dari bercocok tanam. Jenis pertanian waktu itu sebagian sawah, sebagian lagi kebun buah-buahan, seperti duren, nangka, pohon melinjo, dukuh, sedangkan tanaman lainnya adalah singkong, jagung, pisang, sayuran tertentu. Waktu itu ada sementara orang yang mempunyai kerbau, dan banyak keluarga yang anak-anaknya waktu itu pekerjaannya sehabis pulang sekolah menggembalakan kerbau (ngangon kebo). Kehidupan mereka dihabiskan di sawah atau perkebunan. Mereka saling berkomunikasi antar warga seperti persiapan saat tanam, saling pinjam modal, hingga saat panen dalam pemasarannya. Kegiatan seperti ini sudah menjadi agenda rutin masyarakat saat itu, hingga timbul saling memiliki dan kebersamaan diantara mereka. Bahkan yang tidak punya sawahpun, diikut sertakan sebagai pekerja, sehingga sama-sama menikmati rizkinya.

Tetapi ketika perkembangan masyarakat mulai dirasa, banyak warga mulai berubah mata pencahariannya. Pertanian dan perkebunan tidak lagi menjadi satu-satunya mata pencaharian yang bisa diandalkan untuk menunjang kehidupannya. Mata pencaharian sebagai pedagang adalah mereka yang membuka warung barang-barang kelontong atau warung makanan yang dibuka di rumah mereka sendiri. Beberapa warung kelontong tadi tampak cukup lengkap menyediakan kebutuhan sehari-hari, seperti gula, kopi, sabun, 
rokok, minyak kelapa, buku tulis dan lain-lain. Untuk warung makanan yang menyediakan nasi dengan lauknya pada pagi hari, siang sampai sore menyediakan makanan seperti goreng pisang, goreng tahu, lontong, dengan minuman teh manis, dan kopi.

Proses integrasi masyarakat lewat kegiatan perekonomian, di samping melalui proses jual beli di pasar, juga ditandai adanya koperasi yang bernama "Citra Murni Mandiri". Koperasi ini dikelola oleh beberapa marga yang ada yang didalamnya ada tokoh agama, masyarakat dari berbagai agama dan etnis Kampung Sawah, seperti KH. Rahmadi Afif, Maria Oyan dan lainnya. Serta beranggota terdiri dari bermacam-macam etnis dan agama di Kampung Sawah. Sedangkan bagi para ibu-ibunya mempunyai perkumpulan arisan masingmasing marganya. Hal ini dilakukan dalam rangka mengikat marga yang ada di Kampung Sawah agar tidak bercerai berai.

\section{Simpulan}

Dalam sejarahnya nama marga yang ada di Kampung Sawah telah ada sejak lama. Ini menunjukan bahwa ikatan kekerabatan masyarakat tersebut telah terjalin dengan baik. Sistem marga yang dibangunnya telah mampu mewujudkan kebersamaan, silaturhami tetap terjaga dan keikatan keluarga agar tidak bercerai berai diantara mereka. Sistem marga telah menjadikan kehidupan masyarakat Kampung Sawah sangat plural, toleran dan saling menghormati satu dengan yang lainnya. Sistem marga di Kampung Sawah bisa menjadi contoh daerah lain dalam menjaga kesatuan dan keutuhan antar warganya. Bahkan dengan sistem marga seperti itu sistem kekerabatan masyarakat Kampung Sawah menjadi luas dan kuat, dengan pluralitas keagamaan. Hingga saat ini keragaman pemeluk agama di Kampung sawah tidak pernah menjadi konflik, sebab diikat oleh antarmarga mereka sendiri.

\section{Daftar Pustaka}

Anthonius, Bungaran. 2006. Struktur Sosial dan Struktur Politik Batak Toba hingga 1945. Jakarta: Yayasan Obor Indonesia.

Effendi, Sofian. 1996. Membangun Martabat Manusia. Yogyakarta: Gadjah Mada Press.

Haviland, William A. 1985. Anthropology, Terjemahan R.G. Soekadijo. Jakarta: Erlangga. 
Koentjaraningrat. 1998. Pengantar Antropologi Jilid 2. Jakarta: Rineka Cipta.

Koentjaraningrat. 2002. Manusia dan Kebudayaan di Indonesia. Jakarta: Djambatan

Kozok, Uli. 1999. Warisan Leluhur Sastra Lama dan Aksara Batak. Jakarta: Gramedia.

Mainarno, Eko A. 2011. Manusia dalam Kebudayaan dan Masyarakat. Jakarta: Salemba Humanika.

Praptanto, Aloisus Eko. 2011. Sepangkeng Kisah Gereja Katolik Kampung Sawah. Bekasi: Seksi Komunikasi Sosial Paroki Santo Servatius.

Simanjuntak, Bungaran Antonius.2006. Struktur Sosial dan Sistem Politik Batak Toba hingga 1945. Jakarta: Yayasan Obor Indonesia.

Suyono, Ariyono dan Siregar, Aminuddin. 1985. Kamus Antropologi. Jakarta: Akademika Pressindo.

Widjaja, A. 1986. Manusia Indonesia: Individu, Keluarga dan Masyarakat. Jakarta: Akademika Pressindo. 